\title{
Effective use of learning mastery strategy on the level of performing some basic Skills in field hockey for faculty of physical education female students \\ *Dr/ Shimaa Maher Ahmed Mohamed
}

Intro and search trouble:

that with learning to master, scientific material is divided into small educational units, students are assigned to read the unit and prepare its related questions for discussion during the lecture and a student does pass end-to-end test, each without passing an $80 \%$ mastery test, then studying more activities, or moving to the next unit, and if he doesn't get his proficiency, offer him therapeutic activities until he's mastered.(14:55)

And by teaching the researcher to field hockey for second female students period of physical education college at Assiut University, The researcher noticed that alarge proportion of the students can't perform the skill of( hitting a ball with the flat face of astickflatting the ball with the flat face of astick-carrying a ball with the flat fact of astick) perfectly during practical lectures which caught the researcher attention. This suggests that the learning process is experiencing certaion difficulties. This may be due to the teaching method ordering teaching which is based on verbal explanation and the functional skill model there fore, it was necessary to use modern teaching methods with their enormous potential to design educational programs and implement them during teaching lessons for some core field hockey skills using the mastery learning strategy. This helps to enhance the education process and to preseut it will in order to achieve quality performance. So the researcher I suggested to use the learning strategy to master these skills to improve the level of female students and to achieve proficiency in learning these skills, by using the stages of learning mastery strategy (preparation stage- actual learning stage- learning mastery stage) these stages are used as part of the teaching course in the teaching lesson pillar for each of the skills to be mastered.

Search objective:

Lecturer curriculum department and teaching physical education (field hockey) at the faculty of physical Education Assuit University. 
This search aims to identify: The effect of using the learning mastery strategy to perfrorm certain basic skills in field hockey.

\section{Search hypothesis:}

1- There are statistically differences between the preand post measurements of the trial group (mastery learning) in the performance level at some basic skills in field hockey for post measurements. 2- There are statistically differences between the preand-post measurements of the control group (ordering learning) in the performance level at some basic skills in field hockey for post measurements.

3- There are statistically significanl differences between the two post - measurements for the trial and disciplined group in the performance level at some basic skills in field hockey for the trial group.

\section{Research procedures and plan: \\ Search method:}

the researcher used the experimental method by using pre- and- post measurements of two group, one is trial and the other is control because it suits the nature of the research.

The research community:

The research community represents the (190) female students of second Grad of physical education college at Assiut University (20192020).

\section{The research sample:}

It was chosen in the deliberated, random way from second group female students of physical education college at Assiut University and their number was (20) students, (10) of them for the disciplined group and (10) for the trial group, statistic profile of the research sample and table (1) shows that.

Table (1)

Arithmetical mean, standard deviation, moderator, spawning and flattening factors for research sample At some growth variables and physical / skill tests under research $(\mathrm{No}=20)$

\begin{tabular}{|c|c|c|c|c|c|c|c|c|c|}
\hline No & \multicolumn{3}{|c|}{ Variables } & $\begin{array}{c}\text { Measuring } \\
\text { unit }\end{array}$ & $\begin{array}{c}\text { Arithmetical } \\
\text { mean }\end{array}$ & $\begin{array}{r}\text { standard } \\
\text { deviation }\end{array}$ & moderator & $\begin{array}{l}\text { Spawning } \\
\text { factor }\end{array}$ & $\begin{array}{c}\text { flattening } \\
\text { factors }\end{array}$ \\
\hline 1 & \multirow{3}{*}{ ن } & \multicolumn{2}{|c|}{ Age } & Year & 19.77 & 0.41 & 20 & -1.42 & 0.16 \\
\hline$r$ & & \multicolumn{2}{|c|}{ Length } & $\mathrm{Cm}$ & 159.6 & 4.50 & 158 & 0.99 & 0.09 \\
\hline$r$ & & \multicolumn{2}{|c|}{ Weight } & $\mathrm{Kg}$ & 62.78 & 9.84 & 64.07 & -0.04 & -1.34 \\
\hline \multirow[t]{2}{*}{4} & & \multirow{2}{*}{$\begin{array}{c}\text { Fist } \\
\text { strength }\end{array}$} & Right & $\mathrm{Kg}$ & 19.35 & 4.41 & 20 & -0.77 & 0.35 \\
\hline & & & Left & $\mathrm{Kg}$ & 19.25 & 5.01 & 20 & -0.52 & -0.58 \\
\hline$\circ$ & \multirow{4}{*}{ 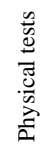 } & \multicolumn{2}{|c|}{ Running $400 \mathrm{~m}$. sprint } & Min. & 1.75 & 0.47 & 1.57 & 0.48 & -1.25 \\
\hline 7 & & \multicolumn{2}{|c|}{$\begin{array}{l}\text { Stem twisting forward } \\
\text { from standing }\end{array}$} & $\mathrm{cm}$. & 10.5 & 5.23 & 11 & 0.02 & -1.57 \\
\hline 7 & & \multicolumn{2}{|c|}{ Baro for agility } & Second & 27 & 3.17 & 26 & 0.33 & 0.81 \\
\hline$\Lambda$ & & \multicolumn{2}{|c|}{ Sprint $30 \mathrm{~m}}$. & Second & 6.05 & 1.23 & 6 & 0.82 & 0.54 \\
\hline
\end{tabular}


Follow Table (1)

Arithmetical mean, standard deviation, moderator, spawning and flattening factors for research sample At some growth variables and physical / skill tests under research $(\mathrm{No}=20)$

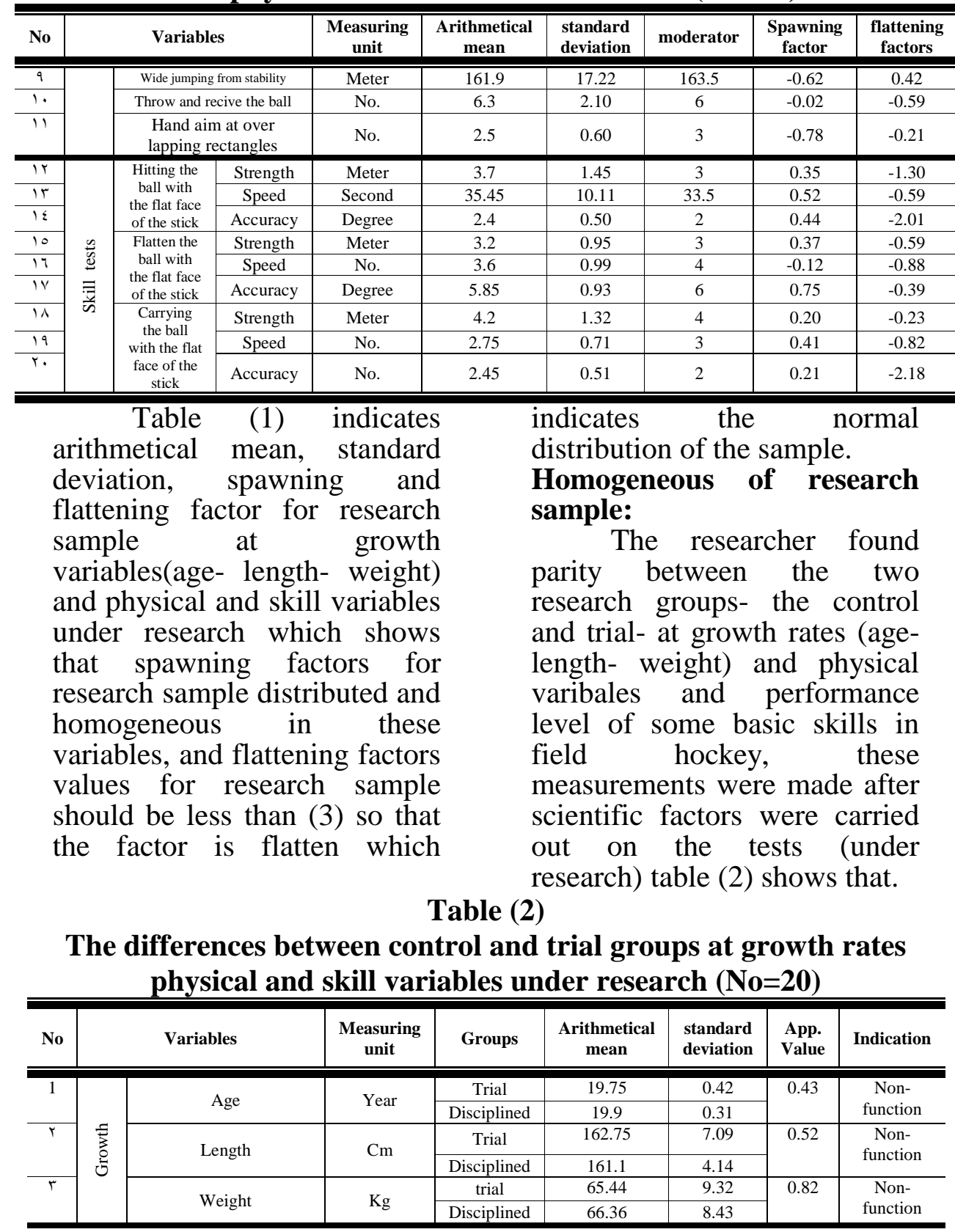


Follow Table (2)

The differences between control and trial groups at growth rates physical and skill variables under research $\left(\mathrm{No}_{\mathbf{2}}=20\right)$

\begin{tabular}{|c|c|c|c|c|c|c|c|c|c|}
\hline No & \multicolumn{3}{|c|}{ Variables } & $\begin{array}{c}\text { Measuring } \\
\text { unit }\end{array}$ & Groups & $\begin{array}{c}\text { Arithmetical } \\
\text { mean }\end{array}$ & $\begin{array}{l}\text { standard } \\
\text { deviation }\end{array}$ & $\begin{array}{l}\text { App. } \\
\text { Value }\end{array}$ & Indication \\
\hline \multirow[t]{4}{*}{4} & & \multirow{4}{*}{$\begin{array}{c}\text { Fist } \\
\text { strength }\end{array}$} & \multirow{2}{*}{ Right } & \multirow{2}{*}{$\mathrm{Kg}$} & trial & 19.9 & 5.4 & \multirow{2}{*}{0.61} & \multirow{2}{*}{$\begin{array}{l}\text { Non- } \\
\text { function }\end{array}$} \\
\hline & & & & & Disciplined & 18.5 & 5.2 & & \\
\hline & & & \multirow{2}{*}{ Left } & \multirow{2}{*}{$\mathrm{Kg}$} & trial & 19.9 & 5.4 & \multirow{2}{*}{0.76} & \multirow{2}{*}{$\begin{array}{l}\text { Non- } \\
\text { function }\end{array}$} \\
\hline & & & & & Disciplined & 19.3 & 5.1 & & \\
\hline \multirow[t]{2}{*}{0} & \multirow{14}{*}{ 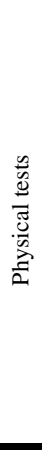 } & \multirow{2}{*}{\multicolumn{2}{|c|}{ Running $400 \mathrm{~m}$. sprint }} & \multirow{2}{*}{ Min. } & trial & 1.6 & 0.4 & \multirow{2}{*}{0.09} & \multirow{2}{*}{$\begin{array}{l}\text { Non- } \\
\text { function }\end{array}$} \\
\hline & & & & & Disciplined & 1.8 & 0.50 & & \\
\hline \multirow[t]{2}{*}{7} & & \multirow{2}{*}{\multicolumn{2}{|c|}{$\begin{array}{l}\text { Stem twisting forward } \\
\text { from standing }\end{array}$}} & \multirow{2}{*}{$\mathrm{cm}$. } & trial & 8.6 & 3.9 & \multirow{2}{*}{0.16} & \multirow{2}{*}{$\begin{array}{l}\text { Non- } \\
\text { function }\end{array}$} \\
\hline & & & & & Disciplined & 7.2 & 3.9 & & \\
\hline \multirow[t]{2}{*}{7} & & \multirow{2}{*}{\multicolumn{2}{|c|}{ Baro for agility }} & \multirow{2}{*}{ Second } & trial & 24.2 & 1.8 & \multirow{2}{*}{0.01} & Non- \\
\hline & & & & & Disciplined & 27.5 & 4.1 & & function \\
\hline$\wedge$ & & Snri & $0 \mathrm{~m}$ & Second & trial & 12.0 & 0.5 & 023 & Non- \\
\hline & & spin & . & Sectila & Disciplined & 12.3 & 1.6 & 0.25 & function \\
\hline 9 & & Wide ju & ing from & Meter & trial & 1.2 & 15.3 & 068 & Non- \\
\hline & & st & ity & Niver & Disciplined & 1.4 & 21.8 & 0.00 & function \\
\hline 1. & & Throw a & ecive the & $\mathrm{No}_{0}$ & trial & 8.0 & 2.5 & 093 & Non- \\
\hline & & & & 100. & Disciplined & 7.0 & 1.8 & 0.73 & function \\
\hline 11 & & Hand & at over & No & trial & 2.8 & 0.4 & 050 & Non- \\
\hline & & lapping & tangles & No. & Disciplined & 2.7 & 0.48 & 0.59 & function \\
\hline ir & & & Strenoth & Meter & trial & 1.80 & 3.2 & 058 & Non- \\
\hline & & the ball & 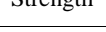 & Nicter & Disciplined & 1.70 & 1.5 & 0.00 & function \\
\hline 15 & & with the & Sneed & Second & trial & 31.3 & 7.7 & & Non- \\
\hline & & flat face & speed & seconta & Disciplined & 35.9 & 9.6 & 0.16 & function \\
\hline $1 \varepsilon$ & & of the & Accuracy & Deoree & trial & 3.2 & 1.3 & & Non- \\
\hline & & & Accuracy & Degree & Disciplined & 2.4 & 0.5 & 0.12 & function \\
\hline 10 & & Flatten & Strenoth & Meter & trial & 6.9 & 2.1 & & Non- \\
\hline & & the ball & Sutrigti & 19ter & Disciplined & 2.5 & 1.1 & 0.01 & function \\
\hline 17 & $\underline{3}$ & with the & Speed & No. & trial & 4.3 & 1.4 & & Non- \\
\hline & $\overline{\bar{z}}$ & flat face & & & Disciplined & 3.3 & 1.1 & 0.11 & function \\
\hline iv & $n$ & $\begin{array}{l}\text { of the } \\
\text { stick }\end{array}$ & Accuracy & Degree & trial & 4.9 & 1.6 & & Non- \\
\hline & & & Returacy & Degiee & Disciplined & 5.8 & 1.0 & 0.05 & function \\
\hline 11 & & Carrying & Strength & Meter & trial & 3.6 & 1.1 & & Non- \\
\hline & & the ball & 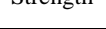 & 1010 & Disciplined & 2.6 & 1.0 & 0.01 & function \\
\hline 19 & & with the & Sneed & $N_{0}$ & trial & 5.2 & 1.2 & & Non- \\
\hline & & flat face & speed & 100. & Disciplined & 5.3 & 0.6 & 0.02 & function \\
\hline r. & & of the & Accuracy & No. & trial & 4.4 & 0.8 & 0.03 & Non- \\
\hline & & & Returacy & 100. & Disciplined & 4.6 & 0.5 & & function \\
\hline
\end{tabular}

"app." Value at level $0.05=2.09 /$ "m" = arithmetical mean / "s" = standard deviation

From table (2) there are no statistical differences at level (0.05) between trial and control groups in growth rates under research which indicates the two research groups parity in these variables.

\section{Data collection tools:}

- Physical and skill tests to evaluate female students level in performance, attach (3), (5). First survey stndy:

This study carried out on asample of research community and from the basic sample from (17/ 2/2019) to (24/2/2019) In order to find the scientific parameters of the 
physical and skill tests under investigation.

Second survey study:

Aimed at applying some of the courses of the proposed tutorial to see how these lessons could be applied, ensure that mastery learning strategy is used at application procedures and what tools did the application need, and the study achieved its targets.

The supposed tutorial application procedures:

The Pre-measurement:

The Pre-measurement for Variables under research has Carried out for the trial and disciplined groups from (26/ $2 /$ 2019) to (28/2/2019) for the basic sample under research.

\section{The supposed tutorial application and implementation:}

The programme has been Carried out by using mastery learning strategy for some basic skills in field hockey on second group students of faculty of physical education, Assiut university (The trial group), also ordering method is used with the control group (attach 8), the implementation of the program for trial group was for (6) weeks, two lesson aweek, from (3/3/ 2019) to (18/4/2019), and (2) tutorials aweek has been teached, the supposed tutorial program was educational units in educational lesson, the time of the lesson (90) minutes (attach 7).

\section{The post - measurement :}

The post- measurement for disciplined trial groups for skills under research at the same arrangement and conditions of Pre- measurements from (21/4/ 2019) to (23/4/ 2019).

The statistical used processors :

It has been carried out by statistical program "Excel" to process the data statistically, and from the most important statistical methods:

Arithmetical- standard deviationmoderator- spawning factorflattening factor- correlation coefficient- percentage for improvement rates - "app" test equation.

The results show and discussion:

First assumption: There are statisrically differences between pre and post measurements for disciplined group (ordering learning) at the performance Level of some basic skills in field hockey for post-measurement. 
Table (3)

The differences between pre and post measurements and "app" value and improving rate of control group in skill test (under research) $(\mathrm{No}=10)$

\begin{tabular}{|c|c|c|c|c|c|c|c|c|c|c|}
\hline \multirow[t]{2}{*}{ No } & \multirow{2}{*}{\multicolumn{2}{|c|}{ Skill tests }} & \multirow{2}{*}{$\begin{array}{c}\text { Measuring } \\
\text { unit }\end{array}$} & \multicolumn{2}{|c|}{$\begin{array}{c}\text { Pre- } \\
\text { measuring }\end{array}$} & \multicolumn{2}{|c|}{$\begin{array}{c}\text { post- } \\
\text { measuring }\end{array}$} & \multirow[t]{2}{*}{ (app)value } & \multirow{2}{*}{$\begin{array}{c}\text { Differeuce } \\
\text { between } \\
\text { averges }\end{array}$} & \multirow{2}{*}{$\begin{array}{l}\text { Improving } \\
\text { rate }\end{array}$} \\
\hline & & & & $\mathbf{M}$ & $\mathbf{S}$ & $\mathbf{M}$ & $\mathbf{S}$ & & & \\
\hline \multirow{3}{*}{1} & \multirow{3}{*}{$\begin{array}{c}\text { Hitting } \\
\text { ball skill }\end{array}$} & $\begin{array}{c}\text { hitting } \\
\text { strength } \\
\text { test }\end{array}$ & Meter & 1.70 & 1.5 & 9.2 & 0.91 & 3.88 & $v_{0} 0$ & $\% \circ r q . \leqslant \vee$ \\
\hline & & $\begin{array}{l}\text { hitting } \\
\text { speed } \\
\text { test }\end{array}$ & Time & 35.9 & 9.6 & 30.3 & 4.00 & 9.25 & 5.6 & $\% 88.18$ \\
\hline & & $\begin{array}{l}\text { hitting } \\
\text { accuacy } \\
\text { test }\end{array}$ & Degrees & 2.4 & 0.5 & 6.1 & 1.52 & 3.04 & 3.7 & $\% 251,76$ \\
\hline \multirow{3}{*}{2} & \multirow{3}{*}{$\begin{array}{c}\text { Flatlen } \\
\text { ball skill }\end{array}$} & $\begin{array}{l}\text { flatlen } \\
\text { strength } \\
\text { test }\end{array}$ & Meter & 2.5 & 1.1 & 8.1 & 1.52 & 3.67 & 5.6 & $\%$ \%rl.。 \\
\hline & & $\begin{array}{l}\text { flatlen } \\
\text { speed } \\
\text { test }\end{array}$ & No & 3.3 & 1.1 & 10.8 & 1.47 & 3.49 & $v_{0} 0$ & \%rrt.qv \\
\hline & & $\begin{array}{c}\text { flatlen } \\
\text { accuacy } \\
\text { test }\end{array}$ & Degrees & 5.8 & 1.0 & 6.5 & 1.08 & 8.96 & $\cdot v$ & \%) \\
\hline \multirow{3}{*}{3} & \multirow{3}{*}{$\begin{array}{l}\text { Carrying } \\
\text { ball skill }\end{array}$} & $\begin{array}{l}\text { carrying } \\
\text { strength } \\
\text { test }\end{array}$ & Meter & 2.6 & 1.0 & 8.5 & 1.35 & 3.45 & 0.9 & $\% 324.32$ \\
\hline & & $\begin{array}{c}\text { carrying } \\
\text { speed } \\
\text { test }\end{array}$ & No & 5.3 & 0.6 & 16.2 & 1.93 & 3.79 & $1 \cdot .9$ & $\% 300.36$ \\
\hline & & $\begin{array}{c}\text { carrying } \\
\text { accuacy } \\
\text { test }\end{array}$ & No & 4.6 & 0.5 & 17.5 & 2.06 & 6.65 & 12.9 & $\% 375.83$ \\
\hline
\end{tabular}

approximatly "app" value at level $(0.05)=2.26$

From table (3) results it appears that there are statistical differences between the degrees average of pre and post measurements for disciplined group in skill performance level at some basic skills in field hockey where value of calculated "app" is between $(9.25: 3.04)$ and it is more than the value of "app" at level (0.05) and from table it is appear that the improving rate between pre and post measurements for disciplined group is between $(539.47 \%$ : $88.18 \%$ ) we notice that the improving rate appears clearly from data schematic view between pre and post measurement for disciplined group at some basic skills (under research) where the amproving rate appears clearly, it us less in time tests and more in the other tests at post measurement for dis Ciplined group at some basic skills (under research). 
"The researcher" sees that the improving that happened at the performance level of some basic skills in field hockey at disciplined group to use ordering learning method through practical model presentation and simple verbal explanation about the skill under research, and the positive influence of control group results because of the importance of teacher existence who gives clear idea about good performance (the model) that makes it more effective, and present good feed back to the improving the performance level of disciplined group students at skills performance under research this result agrees with the study of " Rayan Fekry hassan " (2004) (13), and the study of " Abd el- karim Mahmoud abd elhalim" (2006)(1), that ordering learning method from the direct methods for quick data and skills acqwaintance from teacher to learner where the teacher feels excellence and educational situation control and managing environmental conditions during learning $(13: 128)(1: 248)$.

Table (4)

The differences between pre and post measurements and "app" value and improving rate of trial group in skill tests (under research) (sample $=10)$

\begin{tabular}{|c|c|c|c|c|c|c|c|c|c|c|}
\hline \multirow[t]{2}{*}{ No } & \multirow{2}{*}{\multicolumn{2}{|c|}{ Skill tests }} & \multirow{2}{*}{$\begin{array}{c}\text { Measuring } \\
\text { unit }\end{array}$} & \multicolumn{2}{|c|}{$\begin{array}{c}\text { Pre- } \\
\text { measuring }\end{array}$} & \multicolumn{2}{|c|}{$\begin{array}{c}\text { post- } \\
\text { measuring }\end{array}$} & \multirow[t]{2}{*}{ (app)value } & \multirow{2}{*}{$\begin{array}{c}\text { Differeuce } \\
\text { between } \\
\text { averges }\end{array}$} & \multirow{2}{*}{$\begin{array}{c}\text { Improving } \\
\text { rate }\end{array}$} \\
\hline & & & & $\mathbf{m}$ & $\mathbf{S}$ & M & $\mathbf{S}$ & & & \\
\hline \multirow{3}{*}{1} & \multirow{3}{*}{$\begin{array}{l}\text { Hitting } \\
\text { ball skill }\end{array}$} & $\begin{array}{c}\text { hitting } \\
\text { strength test }\end{array}$ & Meter & 1.80 & 3.2 & 11.4 & 0.96 & 5.9 & 9.7 & $\% 631.53$ \\
\hline & & $\begin{array}{c}\text { hitting } \\
\text { speed test }\end{array}$ & Time & 31.3 & 7.7 & 27.8 & 4.73 & 3.42 & r.o & $\% \wedge \varepsilon . \vee \wedge$ \\
\hline & & $\begin{array}{c}\text { hitting } \\
\text { accuacy test }\end{array}$ & Degrees & 3.2 & 1.3 & 9.5 & 0.52 & 9.09 & $7 . r$ & $\% 293.67$ \\
\hline \multirow{3}{*}{2} & \multirow{3}{*}{$\begin{array}{l}\text { Flatlen } \\
\text { ball skill }\end{array}$} & $\begin{array}{c}\text { flatlen } \\
\text { strength test }\end{array}$ & Meter & 6.9 & 2.1 & 10.2 & 0.91 & 9.27 & 3.3 & $\% 140.92$ \\
\hline & & $\begin{array}{c}\text { flatlen } \\
\text { speed test }\end{array}$ & No & 4.3 & 1.4 & 16.2 & 1.47 & 4.04 & 11.9 & $\% 372.44$ \\
\hline & & $\begin{array}{c}\text { flatlen } \\
\text { accuacy test }\end{array}$ & Degrees & 4.9 & 1.6 & 9.5 & 1.43 & 5.49 & 4.6 & $\% 188.97$ \\
\hline \multirow{3}{*}{3} & \multirow{3}{*}{$\begin{array}{l}\text { Carrying } \\
\text { ball skill }\end{array}$} & $\begin{array}{c}\text { carrying } \\
\text { strength test }\end{array}$ & Meter & 3.6 & 1.1 & 12.8 & 1.47 & 5.81 & $9 . r$ & $\% 351.95$ \\
\hline & & $\begin{array}{c}\text { carrying } \\
\text { speed test }\end{array}$ & No & 5.2 & 1.2 & 23.3 & 1.88 & 4.35 & 11.1 & $\% 442.87$ \\
\hline & & $\begin{array}{c}\text { carrying } \\
\text { accuacy test }\end{array}$ & No & 4.4 & 0.8 & 23.6 & 3.09 & 4.58 & 19.2 & $\% 531.96$ \\
\hline
\end{tabular}

"app." value at level $(0.05)=2.26$

From table (4) results it appears that there are statistical differences between the degrees average of pre and post measurements for trial group for post measurement degrees

at performance level for some basic skills (under research) where value of calculated "app." Is between (9.27: 3.42) and it is more than the value of "app." Value at level (0.05). 
And from the table it appears that improving rate between pre and post measurements for trial group is between (\%631.53 : \%84.78) and this due the followed educational program and what it contains from moving activities and various, different applicable exercises.

"The researcher" sees that the improvement that happened at the performance level of some basic skills in field hockey for trial group because of the existence of a lot of educational alternatives which exciting the learner and motivate him to do the best and not to be bored, also this strategy helps each learner to learn the skill according to his self speed, in addition to correction of errors and no time fore learning where every learner takes a sufficient time at learning and present feed back and moving to next unit after mastering (80\%) from educational homework which lead to skill absorption by learners (under re search) in abetter way.

This result agrees with the study of "Al-motwaly Ebrahim ahmed" (2003) (6), "Hegazy Wael mahmoud" (2006) (7), "Nasr- Eldin mostafa mohamed" (2007) (10), " Ahmed Ahmed adel" (2009) (3) and " Abo Abdoun Fatma mahmoud" (2011) (2), that it is important touse mastery learning strategy and what it includes from educational alternatives in better motor skill acquisition.

This result agrees with "others Makarem abo harga" (2001) that when using educational means we have to basic elementes from leaning elements and they are active participation element from learner side, and feed back element which improve motor performance (11: 19).

\section{Table (5)}

The differences between the two post measerments for disciplined and trial groups in skill tests (under research) $($ sample $=20)$

\begin{tabular}{|c|c|c|c|c|c|c|c|c|c|}
\hline \multirow[t]{2}{*}{ No } & \multirow{2}{*}{\multicolumn{2}{|c|}{ Skill tests }} & \multirow[t]{2}{*}{$\begin{array}{c}\text { Measuring } \\
\text { unit }\end{array}$} & \multicolumn{2}{|c|}{$\begin{array}{c}\text { post- } \\
\text { measuring for } \\
\text { disciplined } \\
\text { group } \\
\end{array}$} & \multicolumn{2}{|c|}{$\begin{array}{l}\text { post- } \\
\text { measuring } \\
\text { trial group }\end{array}$} & \multirow[t]{2}{*}{$\begin{array}{l}\text { (app) } \\
\text { value }\end{array}$} & \multirow[t]{2}{*}{$\begin{array}{c}\text { Differeuce } \\
\text { between } \\
\text { averges }\end{array}$} \\
\hline & & & & $\mathbf{M}$ & $\mathbf{S}$ & $\mathbf{m}$ & $\mathbf{S}$ & & \\
\hline \multirow[t]{3}{*}{1} & \multirow[t]{3}{*}{$\begin{array}{r}\text { Hitting } \\
\text { ball skill }\end{array}$} & $\begin{array}{l}\text { hitting } \\
\text { strength } \\
\text { test }\end{array}$ & Meter & 9.2 & 1.03 & 11.4 & 0.96 & 4.86 & r. \\
\hline & & $\begin{array}{l}\text { hitting } \\
\text { speed } \\
\text { test }\end{array}$ & Time & 44.3 & 4.27 & 27.8 & 4.73 & 6.74 & 16.5 \\
\hline & & $\begin{array}{l}\text { hitting } \\
\text { accuacy } \\
\text { test }\end{array}$ & Degrees & 6.1 & 1.37 & 9.5 & 0.52 & 3.82 & 3.4 \\
\hline
\end{tabular}


Follow Table (5)

The differences between the two post measerments for disciplined and trial groups in skill tests (under research) (sample =20)

\begin{tabular}{|c|c|c|c|c|c|c|c|c|c|}
\hline \multirow[t]{2}{*}{ No } & \multirow{2}{*}{\multicolumn{2}{|c|}{ Skill tests }} & \multirow[t]{2}{*}{$\begin{array}{c}\text { Measuring } \\
\text { unit }\end{array}$} & \multicolumn{2}{|c|}{$\begin{array}{c}\text { post- } \\
\text { measuring for } \\
\text { disciplined } \\
\text { group }\end{array}$} & \multicolumn{2}{|c|}{$\begin{array}{c}\text { post- } \\
\text { measuring } \\
\text { trial group }\end{array}$} & \multirow[t]{2}{*}{$\begin{array}{l}\text { (app) } \\
\text { value }\end{array}$} & \multirow[t]{2}{*}{$\begin{array}{c}\text { Differeuce } \\
\text { between } \\
\text { averges }\end{array}$} \\
\hline & & & & $\mathbf{M}$ & $\mathbf{S}$ & $\mathbf{m}$ & $\mathbf{S}$ & & \\
\hline \multirow[t]{3}{*}{2} & \multirow[t]{3}{*}{$\begin{array}{r}\text { Flatlen } \\
\text { ball skill }\end{array}$} & $\begin{array}{c}\text { flatlen } \\
\text { strength } \\
\text { test } \\
\end{array}$ & Meter & 8.1 & 1.85 & 10.2 & 0.91 & 5.37 & Y. 1 \\
\hline & & $\begin{array}{c}\text { flatlen } \\
\text { speed test }\end{array}$ & No & 10.8 & 2.09 & 16.2 & 1.47 & 4.26 & 5.4 \\
\hline & & $\begin{array}{c}\text { flatlen } \\
\text { accuacy } \\
\text { test }\end{array}$ & Degrees & 6.5 & 1.26 & 9.5 & 1.43 & 3.26 & 3.0 \\
\hline \multirow[t]{3}{*}{3} & \multirow[t]{3}{*}{$\begin{array}{l}\text { Carrying } \\
\text { ball skill }\end{array}$} & $\begin{array}{l}\text { carrying } \\
\text { strength } \\
\text { test }\end{array}$ & Meter & 8.5 & 1.08 & 12.8 & 1.47 & 3.43 & $\varepsilon . r$ \\
\hline & & $\begin{array}{c}\text { carrying } \\
\text { speed test }\end{array}$ & No & 16.2 & 2.04 & 23.3 & 1.88 & 3.06 & 7.1 \\
\hline & & $\begin{array}{l}\text { carrying } \\
\text { accuacy } \\
\text { test }\end{array}$ & No & 17.5 & 1.43 & 23.6 & 3.09 & 4.67 & 7.1 \\
\hline
\end{tabular}

"app." value at level $(0.05)=2.09$ From table (5) it appears that there are statistical differences between the degrees average of the two post measurement for disciplined and trial groups where value of calculated"app." Is between (6.74: 3.06) and it is more than the value of "app." Value at level (0.05).

"The researcher" sees that improving at trial group individuals due to multiple feed back sources through showing a lot of educational alternatives (the teachermoving pictures by computerstable pictures by trans parency) in addition to taking into account individual

differences between learners where the learner who can get mastery or from verbal explanation and giving model then giving sufficient time at training and learning with errors correction and presenting feedback differs from the learner who understand and master at next stage by using another educational alternative through (C.D) show and knowing skill educational steps under research.

And this differs from the learner who don't master through the previous two stages where they are offered stable alternative which is 
stable pictures show by transparency until the learners getting mastery through the three stages or getting some basic skills in field hockey.

This result agrees with the study of "Nasr El-din Mostafa mohamed" (2007) (10), "Ahmed Ahmed adel" (2009) (3), " El-Halfy Haidar majid" (2010) (5), "Abo Abdoun Fatma mahmoud" (2011) (2), "Magdy sara mohamed" (2013) (8), and " Matar Diaa thamer" (2014) (9), where the studies emphasized on mastery learning strategy effectiveness at improving skill side of under research skills, and also emphasized on importance of using mastery learning strategy and modern teaching mothods at acquiring motor skills comparing with ordering learning method "Alfred" (2006) indicates that ordering learning method don't give sufficient time for every learner to do more times, and don't let the teacher correct the errors when it appears to all learners, also educational responsibility is upon the teacher through taking decisions about educational unit $(4: 94)$.

This result agrees with the study of "others Mostafa abed el- sameq"(2001) that using educational methods in learning operation gives the learner fead back that results quantitative and quantitative learning, also providing content in proportion to individual differences helps the learner getting to the right level at his own speed. (12: 76)

conclusion: 1-Mastery learning strategy has appositive influence at the performance level of some basic skills in field hockey.

2-Ordering learning method has appositive influence at the performance level of some basic skills in field hockey.

1- Mastery learning strategy exceeds ordering learning method at postmeasurement improving rates than pre-one at performance level some basic skills (under research skills).

1- Recommendations Mastery learning strategy should be used when learning some some basic skills in field hockey.

2- Knowning about the characterisitics and needs of students to develop appropriate curricula and programmes that will help them develop soundly and integrally.

3- The importance of incorporating teaching methods that play an effective role in 
the learning process in line with educational modernization and development and one of them is mastery learning strategy.

\section{Refernces:}

1- Abd El-Karim Mahmoud Abd El-Halim: Physical education teaching dynamics, book center for publishing, Cairo, 2006.

2- Abo Abdoun Fatma

Mahmoud: The effecto fusing mastery learning strategy at shooting performance level from falling at hand ball, science and art sportive magazine, bookbinder (38), faculty of physical education for female students, Helwan university, 2011.

3- Ahmed Ahmed Adel: use specific exercises to learn some beginner's squash skills, Master's letter, faculty of physical education, AlMansoura University 2009.

4- Alfred, B: Problems the Commands Styles in Physical Education, the Journal Educational Research, vol. 114, No. 40,2006.

\section{5- Al-Halfy Haidar Majid:} Using mastery learning effecton learing and keeping some handball shooting skills, Master's letter, faculty of physical education, Misan Universitey, 2010.

\section{6- El-Metwaly Ebrahim}

Ahmed: The effect of some teaching techniques on learning some football skills. Doctorate Letter, faculty of physical education male students, Helwan University 2003.

\section{7- Hegazy Wael Mahmoud:}

The effect of using mastery learning strategy on learning some basic skills for beginners in basket ball, Masters letter, faculty of physical education Port Said, Canal Suez University, 2006.

\section{8- Magdy Sara Mohamed:} mastery learning strategy effectiveness at performance level on some basketball offensive skills for faculty of phculty of physical education for female students, Master's letter, faculty of physical education, Banha University 2013.

9- Matar Diaa Thamer: The mastering method effect by multiple multimedia at learning some basketball offensive skills for beginners from ages (11-12) year, Doctorat letter, faculty of physical education, Al-Qadisya University,2014.

\section{0- Nasr El-Din Mostafa}

Mohamed: The effect of using mastery learning strategy on mandatory exercises performance grade for students of faculty of Physical education in Portsaid, 
scientif research and study magazine at Physical education, No(15), faculty of physical education Port Said, Canal Suez University, 2007.

11- others Makarem Abo Harga: Teaching technology and its Techniques at physical education, book center for publishing,cairo, 2001.

12- others Mostafa Abed ElSameq: communication and educational media are basic readings for student and teacher, book center for publishing, Cairo, 2001.

13- Rayan Fekry Hassan:

Teaching objectives-basesresults evaluation-application, book world, Cairo, 2004.

14- Salim Ahmed Mohamed:

Single education and its strategies, Ayat Center for computer and printing, Zakazik 2009. 